\title{
In Vivo Penetration of Antibiotics into Sputum in Cystic Fibrosis
}

\author{
B. A. SAGGERS and DAVID LAWSON \\ From Queen Mary's Hospital for Children, Carshalton, Surrey
}

The control of respiratory tract infections in cystic fibrosis has for many years utilized a wide range of antibiotics. The effect of administering one or more antibiotics to combat an invading organism has, as might te expected, been variable. We have attempted here to determine some of the factors that are responsible for these variations in the hope that a more effective chemotherapeutic control might result.

The cases studied in this series were limited to those with extensive lung damage, as only in these cases could enough sputum be obtained for assay purposes. The results we have obtained, therefore, do not indicate the value of the test antibiotic in prophylaxis.

\section{Materials and Methods}

Test antibiotics. Antibiotics and dosages commonly used in the treatment of cystic fibrosis were studied (Table I). The dose range of the test antibiotics was adjusted according to the age of the patient studied. The antibiotic dose was also varied to determine whether a double dose of antibiotic would increase the sputum level significantly.

Sputum samples. All the sputum samples used in this survey were taken from cystic fibrosis patients undergoing antibiotic therapy for the control of bacterial chest infection. Sputum samples were collected in 1-hour or 6-hourly periods as required. The plugs of sputum were separated from the saliva by deep freezing the sample and cutting the sputum away from the surrounding fluid. The sputum samples were then homogenized with pancreatin (May and Delves, 1965) before they were assayed for antibiotic content.

Blood samples. A venous blood sample was taken at the time of the maximum blood level for the particular test antibiotic. The serum obtained in this way was then assayed for antibiotic content.

Estimation of sputum purulence. The sputum purulence level was determined by the microscopical

Received December 20, 1967. examination of a sputum smear stained in methylene blue. The approximate percentage of pus of the sample was graded as $0,1-25,25-50,50-75$, and $75-100$.

\section{Determinations of antibiotic levels.}

In sputum. The antibiotic content of the sputum was determined by microbiological plate assay using the punch hole technique. All antibiotic assays except for the sulphonamides were done in $14 \mathrm{~cm}$. glass Petri dishes, the plate agar being poured in two layers; $50 \mathrm{ml}$. infusion agar of $p \mathrm{H} \mathrm{7.4}$ was used as a base layer, with $25 \mathrm{ml}$. infusion agar as the seeded top layer. The seeded agar was prepared by inoculating $25 \mathrm{ml}$. molten infusion agar at $50^{\circ} \mathrm{C}$. with $0.25 \mathrm{ml}$. of an 18 -hour broth culture of the assay organism. The assay organisms used were those recommended by the National Collection of Type Cultures for the assay of the test antibiotics.

The pancreatin homogenized sputum samples $(0 \cdot 2 \mathrm{ml}$.) were compared with $0.2 \mathrm{ml}$. volumes of antibiotic standards in $p \mathrm{H} 7.4$ phosphate buffer (Sorensen). Erythromycin and lincomycin were assayed in agar at pH 8.0 to increase the sensitivities of these assays.

In serum. The technique for the assay of serum antibiotic levels was the same as for the sputum antibiotic level determinations, except that the antibiotic standards were made up in human serum. Antibiotic-

\section{TABLE I}

Antibiotics and Dosages Commonly Used in Treatment of Cystic Fibrosis

\begin{tabular}{|c|c|c|}
\hline Drug & & Dosage \\
\hline 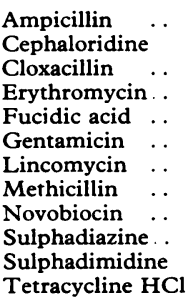 & \begin{tabular}{l|}
$\cdots$ \\
$\cdots$ \\
$\cdots$ \\
$\cdots$ \\
$\cdots$ \\
$\cdots$ \\
$\cdots$ \\
$\cdots$ \\
$\cdots$ \\
$\cdots$ \\
$\cdots$ \\
$\cdots$
\end{tabular} & $\begin{array}{l}250-500 \mathrm{mg} . \times 4 \\
125-250 \mathrm{mg} . \times 4 \\
250-500 \mathrm{mg} . \times 4 \\
250 \mathrm{mg} . \times 4 \\
20 \mathrm{mg} . / \mathrm{kg} . \text { per day } \\
1-2 \mathrm{mg} . / \mathrm{kg} . \text { per day } \\
250-500 \mathrm{mg} . \times 4 \\
250 \mathrm{mg} . \times 4 \\
250-500 \mathrm{mg} . \times 4 \\
0.5-1.5 \mathrm{~g} . \times 4 \\
0.5-1.5 \mathrm{~g} . \times 4 \\
125-250 \mathrm{mg} . \times 4\end{array}$ \\
\hline
\end{tabular}




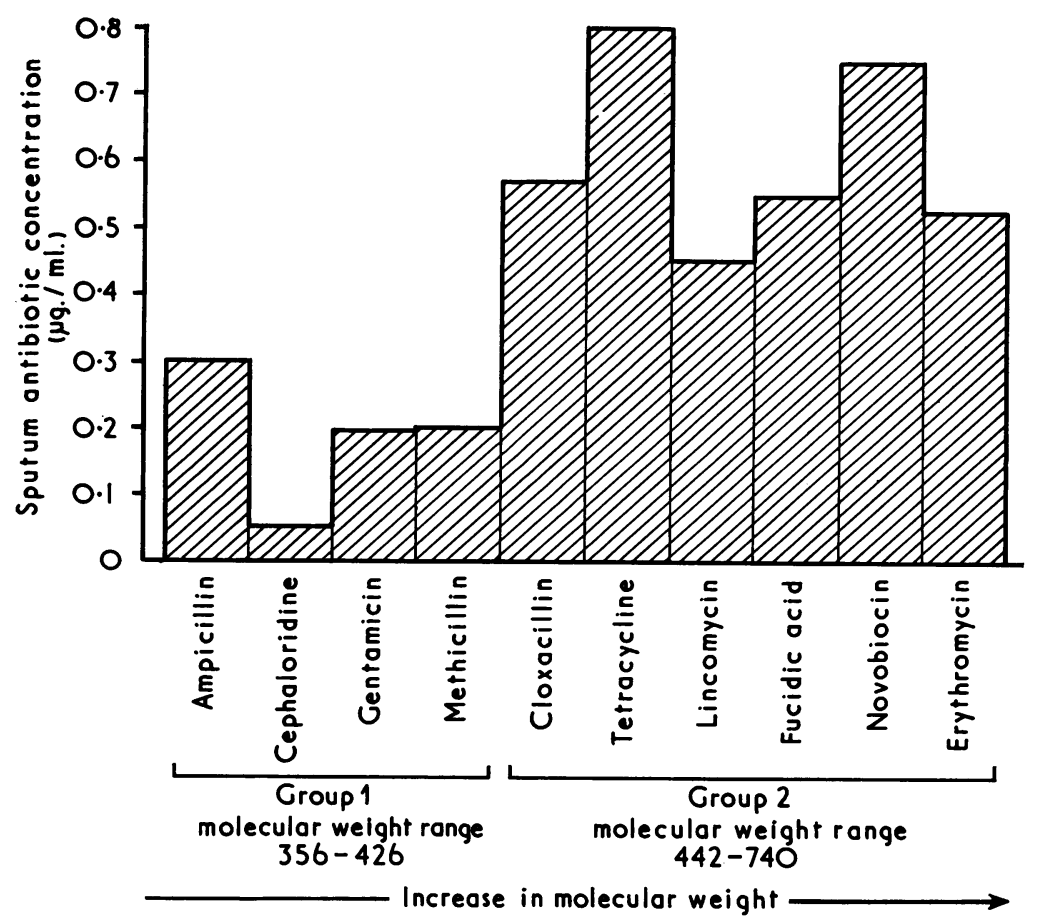

FIG. 1.-The mean concentrations of 10 different antibiotics in cystic fibrosis sputum. The antibiotics are arranged in order of their molecular weights.

free serum samples could not be obtained from the patients under study, so the antibiotic standards were made up in pooled antibiotic-free serum from 20 normal adults containing at least $95 \%$ serum (Bond, 1964).

Sulphonamides. Sulphonamide levels in both sputum and serum were estimated by the chemical method of Bratton and Marshall (1939).

N-acetyl cysteine aerosols. Lawson and Saggers (1965) and Saggers and Lawson (1966) have shown that some antibiotics are inactivated in vitro by $5 \% \mathrm{~N}$-acetyl cysteine (NAC). Experiments were done to determine the effect of aerosolized $20 \%$ NAC on sputum antibiotic levels in fibrocystic patients. Sputum samples were taken at hourly intervals for at least 3 hours before the NAC aerosol, and at intervals of 30 minutes, 1 hour, and 2 hours afterwards. The NAC aerosol was supplied in compressed air through a nebulizer. Care was taken to avoid contact between the aerosol and rubber.

\section{Results}

The results are presented as a general survey, with detailed accounts for each antibiotic.

Sputum levels (general survey). The mean antibiotic levels found in cystic fibrosis sputum are shown in the histogram (Fig. 1). The anti- biotics fell into two groups with regard to their mean obtainable sputum levels. Antibiotics of low molecular weights showed a tendency to give lower sputum levels than those of high molecular weights.

\section{Individual antibiotics}

Ampicillin (12 cases). The serum and sputum levels obtained with ampicillin are shown in Table II. There was considerable individual variation of both serum and sputum levels, ranging from $2 \cdot 1-$ $9 \cdot 2 \mu \mathrm{g} . / \mathrm{ml}$. for serum and from $0 \cdot 01-1 \cdot 0 \mu \mathrm{g} . / \mathrm{ml}$. for sputum. The level of ampicillin in the serum could not be directly correlated with the sputum levels; a patient with $7 \cdot 7 \mu \mathrm{g} . / \mathrm{ml}$. ampicillin in the serum had a sputum level of only $0.03 \mu \mathrm{g} . / \mathrm{ml}$., while a patient with a serum level of $2 \cdot 7 \mu \mathrm{g} . / \mathrm{ml}$. had a sputum level of $0.6 \mu \mathrm{g} . / \mathrm{ml}$. These findings are similar to those of May and Delves (1965).

No correlation between purulence and sputum ampicillin levels was found in our series, as in all cases the expectorated sputum was very purulent due to extensive lung damage. This was generally true for all the antibiotics investigated in this series.

The day-to-day sputum levels in individual patients were usually fairly constant, but on some 
TABLE II

Concentrations of Ampicillin in Sputum and Serum; Dose 250 mg. q.d.s. Orally

\begin{tabular}{c|c|c}
\hline & Ampicillin Concentrations $(\mu \mathrm{g} . / \mathrm{ml})$. \\
\hline & Sputum & Serum \\
\hline 1 & $1 \cdot 0$ & $3 \cdot 4$ \\
2 & $0 \cdot 8$ & $5 \cdot 6$ \\
3 & $0 \cdot 6$ & $2 \cdot 7$ \\
4 & $0 \cdot 45$ & $2 \cdot 1$ \\
5 & $0 \cdot 3$ & $2 \cdot 4$ \\
6 & $0 \cdot 22$ & $7 \cdot 8$ \\
7 & $0 \cdot 1$ & $9 \cdot 2$ \\
8 & $0 \cdot 08$ & $5 \cdot 6$ \\
9 & $0 \cdot 05$ & $2 \cdot 7$ \\
10 & $0 \cdot 03$ & $7 \cdot 7$ \\
11 & $0 \cdot 01$ & $2 \cdot 8$ \\
12 & $0 \cdot 01$ & $2 \cdot 8$ \\
\hline
\end{tabular}

occasions a sharp rise in sputum ampicillin level occurred. No change in sputum purulence was detected in these cases, the rise possibly being due to increased secretions on the lung surface.

The effect of doubling the dose of ampicillin generally produced only a slight rise in the sputum ampicillin content (Fig. 2), less than that expected; this was also true after the use of intramuscular probenicid. These findings suppor the suggestion of May and Delves (1965) that ampicillin may be actively secreted into bronchial secretions.

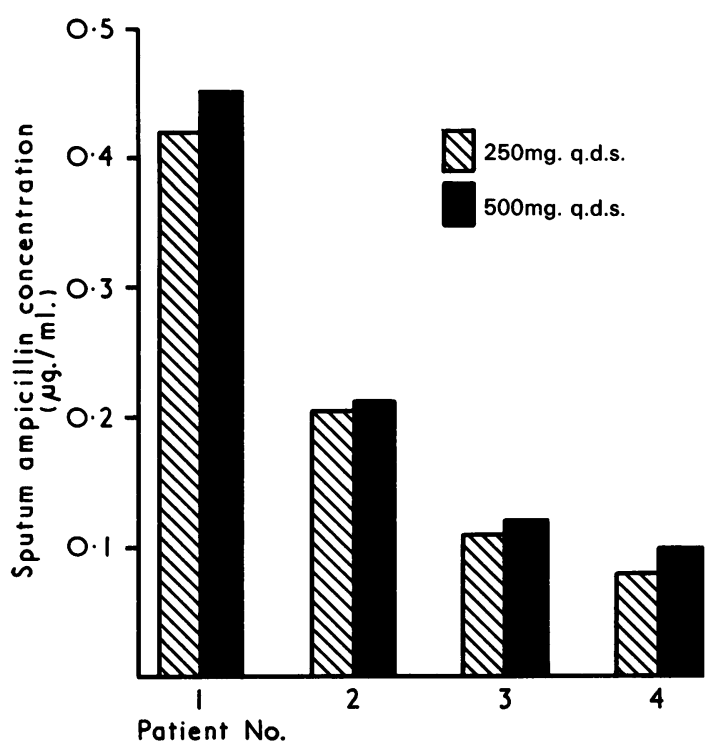

FIG. 2.-The effect of doubling the dose of ampicillin on sputum levels in 4 patients with cystic fibrosis.
TABLE III

Concentration of Cloxacillin in Sputum and Serum; Dose $250 \mathrm{mg}$. q.d.s. Orally

\begin{tabular}{c|c|c}
\hline \multirow{3}{*}{ Patient No. } & Cloxacillin Concentration $(\mu \mathrm{g} . / \mathrm{ml})$. \\
\cline { 2 - 3 } & Sputum & Serum \\
\hline 1 & $1 \cdot 6$ & $8 \cdot 0$ \\
2 & $1 \cdot 1$ & $11 \cdot 0$ \\
3 & $1 \cdot 0$ & $3 \cdot 4$ \\
4 & $0 \cdot 8$ & $4 \cdot 3$ \\
5 & $0 \cdot 72$ & $3 \cdot 8$ \\
6 & $0 \cdot 42$ & $3 \cdot 6$ \\
7 & $0 \cdot 34$ & $4 \cdot 4$ \\
8 & $0 \cdot 3$ & $5 \cdot 0$ \\
9 & $0 \cdot 27$ & $5 \cdot 6$ \\
10 & $0 \cdot 22$ & $4 \cdot 6$ \\
11 & $0 \cdot 05$ & $10 \cdot 0$ \\
12 & $0 \cdot 01$ & $3 \cdot 0$ \\
\hline
\end{tabular}

Cephaloridine (5 cases). This antibiotic was only investigated in a small number of cases, but it appeared that it behaved very like ampicillin. The range of sputum cephaloridine concentrations was found to be between 0.02 and $0.1 \mu \mathrm{g} . / \mathrm{ml}$. No direct correlation between serum and sputum levels was evident; for example, a patient with a serum level of $6.7 \mu \mathrm{g} . / \mathrm{ml}$. had the same sputum level of $0.04 \mu \mathrm{g} . / \mathrm{ml}$. as a patient with $2.4 \mu \mathrm{g} . / \mathrm{ml}$. cephaloridine in the serum.

Cloxacillin (12 cases). Cloxacillin sputum levels were generally higher than those found with previously mentioned antibiotics (Table III). Again no direct correlation was found between serum cloxacillin levels and sputum levels. An increased serum level due to increased dosage produced a slight rise in the sputum level, but again this was never as much as was expected.

One patient showed a slight drop in sputum purulence while on cloxacillin, which was accompanied by a drop in sputum cloxacillin level (Fig. 3). The range of sputum cloxacillin levels in our series was between 0.01 and $1.6 \mu \mathrm{g} . / \mathrm{ml}$., the day-to-day levels in individuals being maintained within narrow limits. There was a tendency for early morning sputum specimens to have a higher cloxacillin content than those collected later in the day, possibly due to a slight build-up in the antibiotic level overnight (Table IV).

Erythromycin (7 cases). The sputum levels for this antibiotic were in a range from $0.01 \mu \mathrm{g} . / \mathrm{ml}$. to $1.4 \mu \mathrm{g} . / \mathrm{ml}$. There was no indication that variations in blood levels had any effect on the erythromycin content of the sputum. 

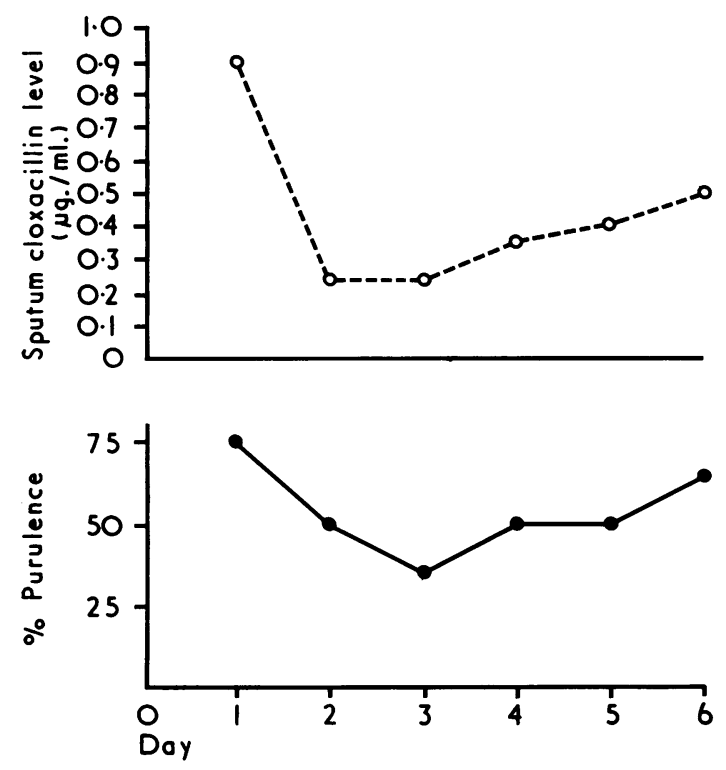

FIG. 3.-One case of cystic fibrosis which showed a relation between sputum purulence and cloxacillin levels.

Fucidic acid (12 cases). Table $\mathrm{V}$ shows the sputum and serum fucidic acid levels from patients receiving fucidic acid $20 \mathrm{mg}$. $/ \mathrm{kg}$. per day. Usually good antibiotic levels were found in the sputum, ranging from 0.1 to $1.6 \mu \mathrm{g} . / \mathrm{ml}$. Again no direct correlation between sputum and serum levels was found. As was observed with cloxacillin, the early morning sputum specimens from most of the patients studied contained more fucidic acid than later sputum samples.

Gentamicin (4 cases). Gentamicin levels in sputum, serum, and urine were assayed using Corynebacterium xerosis as the indicator organism; the results are shown in Table VI. Using the recommended dose of $1 \mathrm{mg}$. $/ \mathrm{kg}$. per day, very low

TABLE IV

Differences in Cloxacillin Levels of Sputum Collected in Morning and Afternoon

\begin{tabular}{c|c|c}
\hline \multirow{2}{*}{ Patient No. } & \multicolumn{2}{|c}{ Sputum Cloxacillin level $(\mu \mathrm{g} . / \mathrm{ml})}$. \\
\cline { 2 - 3 } & Morning Specimen & Afternoon Specimen \\
\hline 1 & 0.6 & 0.55 \\
2 & 0.53 & 0.46 \\
3 & 0.35 & 0.26 \\
4 & 0.35 & 0.20 \\
5 & 0.19 & 0.1 \\
\hline
\end{tabular}

TABLE V

Concentrations of Fucidic Acid in Sputum and Serum (dose $20 \mathrm{mg} . / \mathrm{kg}$. per day)

\begin{tabular}{c|c|c}
\hline \multirow{3}{*}{ Patient No. } & \multicolumn{2}{|c}{ Fucidic Acid Concentrations $(\mu \mathrm{g} . / \mathrm{ml})}$. \\
\cline { 2 - 3 } & Sputum & Serum \\
\hline 1 & $1 \cdot 6$ & $4 \cdot 0$ \\
2 & $1 \cdot 4$ & $11 \cdot 0$ \\
3 & $0 \cdot 7$ & $10 \cdot 5$ \\
4 & $0 \cdot 54$ & $6 \cdot 0$ \\
5 & $0 \cdot 4$ & $9 \cdot 0$ \\
6 & $0 \cdot 4$ & $10 \cdot 4$ \\
7 & $0 \cdot 39$ & $10 \cdot 1$ \\
8 & $0 \cdot 36$ & $14 \cdot 0$ \\
9 & $0 \cdot 25$ & $10 \cdot 0$ \\
10 & $0 \cdot 15$ & $10 \cdot 0$ \\
11 & $0 \cdot 1$ & $5 \cdot 0$ \\
12 & $0 \cdot 1$ & $4 \cdot 0$ \\
\hline
\end{tabular}

levels of gentamicin were detected in the sputum, from $0.01-0.07 \mu \mathrm{g} . / \mathrm{ml}$., with serum levels from $0.23-0.9 \mu \mathrm{g} . / \mathrm{ml}$. It was decided to double the dosage of gentamicin, giving sputum levels between 0.1 and $0.43 \mu \mathrm{g} . / \mathrm{ml}$., with serum levels of $1 \cdot 0-3 \cdot 3$ $\mu \mathrm{g} . / \mathrm{ml}$.

Lincomycin (10 cases). This antibiotic was found in the sputum at similar concentrations to fucidic acid, ranging from $0.05 \mu \mathrm{g} . / \mathrm{ml} .-1.6 \mu \mathrm{g} . / \mathrm{ml}$. There was no direct correlation between the sputum and serum levels in the patients studied, and again a large rise in the serum level was not reflected in the sputum.

Methicillin (10 cases). Methicillin was found in concentrations of $0.06-1.0 \mu \mathrm{g} . / \mathrm{ml}$. in the sputum, with blood levels ranging from $3 \cdot 5-23 \cdot 0 \mu \mathrm{g} . / \mathrm{ml}$. The use of probenicid with this antibiotic had little effect on the sputum antibiotic levels obtained.

Novobiocin (10 cases). The sputum levels of novobiocin showed a wide range from $0 \cdot 03-2 \cdot 4$

TABLE VI

Concentrations of Gentamicin in Sputum and Serum

\begin{tabular}{|c|c|c|c|}
\hline \multirow{2}{*}{ Patient No. } & \multirow{2}{*}{$\begin{array}{c}\text { Daily Dose of } \\
\text { Gentamicin } \\
\text { (mg./kg.) }\end{array}$} & \multicolumn{2}{|c|}{ Gentamicin Level ( $\mu \mathrm{g} . / \mathrm{ml})}$. \\
\hline & & Sputum & Serum \\
\hline $\begin{array}{l}1 \\
\text { "' } \\
2 \\
3 \\
", \\
4\end{array}$ & $\begin{array}{l}1 \\
2 \\
1 \\
2 \\
1 \\
2 \\
1 \\
2\end{array}$ & $\begin{array}{l}0 \cdot 07 \\
0 \cdot 1 \\
0 \cdot 05 \\
0 \cdot 2 \\
0 \cdot 02 \\
0 \cdot 06 \\
0 \cdot 01 \\
0 \cdot 43\end{array}$ & $\begin{array}{l}0 \cdot 23 \\
1 \cdot 0 \\
0 \cdot 25 \\
3 \cdot 3 \\
0 \cdot 9 \\
1 \cdot 3 \\
0 \cdot 52 \\
2 \cdot 2\end{array}$ \\
\hline
\end{tabular}


TABLE VII

Concentrations of Tetracycline in Sputum and Serum (dose $1 \mathrm{~g} . /$ day)

\begin{tabular}{c|c|c}
\hline \multirow{3}{*}{ Patient No. } & \multicolumn{2}{|c|}{ Tetracycline Concentrations $(\mu \mathrm{g} . / \mathrm{ml})}$. \\
\cline { 2 - 3 } & Sputum & Serum \\
\hline 1 & $2 \cdot 3$ & $4 \cdot 7$ \\
2 & $1 \cdot 2$ & $5 \cdot 0$ \\
3 & $1 \cdot 0$ & $2 \cdot 5$ \\
4 & $0 \cdot 9$ & $4 \cdot 0$ \\
5 & $0 \cdot 72$ & $2 \cdot 7$ \\
6 & $0 \cdot 7$ & $5 \cdot 0$ \\
7 & $0 \cdot 7$ & $2 \cdot 7$ \\
8 & $0 \cdot 6$ & $3 \cdot 4$ \\
9 & $0 \cdot 6$ & $1 \cdot 2$ \\
10 & $0 \cdot 36$ & $1 \cdot 4$ \\
11 & $0 \cdot 3$ & $10 \cdot 0$ \\
12 & $0 \cdot 3$ & $5 \cdot 0$ \\
\hline
\end{tabular}

$\mu \mathrm{g} . / \mathrm{ml}$; these values were again independent of blood levels.

Sulphonamides (10 cases). Sulphadiazine and sulphadimidine were the only two sulphonamides studied, but as the results of the determinations were so similar they are considered together. The sulphonamides found in the sputum reached much higher concentrations than any other of the test antibiotics. The levels estimated were for 'free' sulphonamides only, which in this series were independent of blood level. The range of sulphonamide sputum levels was between 0.1-3.76 $\mu \mathrm{g} . / \mathrm{ml}$., with serum levels of $4 \cdot 12-27 \cdot 9 \mu \mathrm{g} . / \mathrm{ml}$.

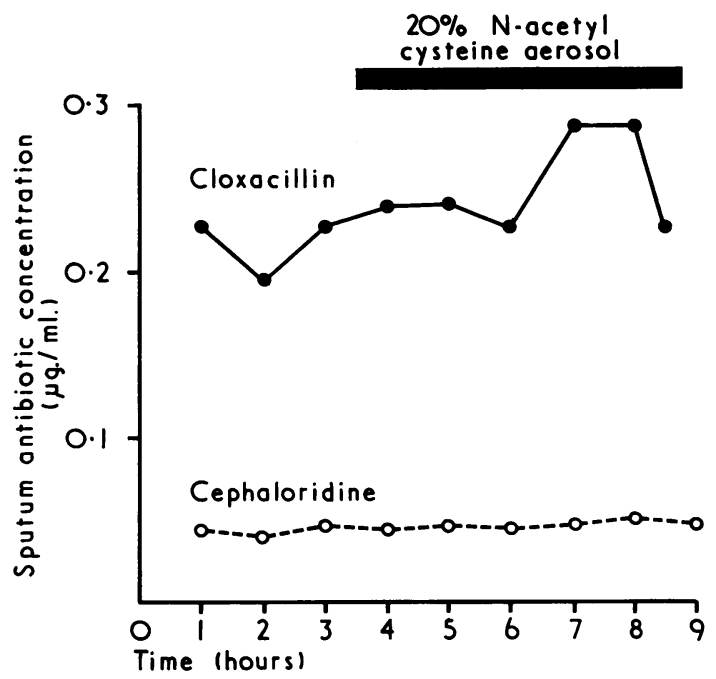

Fig. 4.-Effect of $N$-acetyl cysteine aerosol on sputum antibiotic levels.
Tetracyclines (12 cases). Table VII shows the serum and sputum levels obtained with tetracyclines. There were considerable individual variations in both the serum and sputum levels detected, and again there was no direct correlation between the two levels.

Effect of $\mathbf{N}$-acetyl cysteine on antibiotics. There was no inactivation of the penicillins or cephaloridine in sputum due to the inhalation of $20 \% \mathrm{w} / \mathrm{v} \mathrm{N}$-acetyl cysteine. The results of two determinations are shown in Fig. 4.

\section{Discussion}

The concentrations of the test antibiotics in the sputum proved not to be directly related to blood levels, and an increase in a serum antibiotic content did not necessarily lead to a corresponding rise in the sputum concentration. There appears to be a range of sputum levels for each antibiotic which cannot be varied appreciably by raising the antibiotic blood level after a saturation baseline is reached. This phenomenon has been reported by May and Delves (1965) with ampicillin in bronchitis.

Saggers and Lawson (1966) have shown that the penetration of mucus by antibiotics in vitro is dependent on their molecular weight. This also appears to be borne out to some extent by our findings in vivo. Some of the sputum antibiotic levels obtained could not be predicted on a molecular weight basis, e.g. tetracycline and the sulphonamides. The high levels of tetracycline in cystic fibrosis sputum may be associated with high calcium ion concentration in the sputum.

Close similarity between $p$-aminobenzoic acid and the sulphonamides might well be responsible for the high sputum levels of these drugs. Direct competition between the sulphonamides and $p$ aminobenzoic acid would involve the drug in a different transport mechanism. We have not been able to find any relation between sputum purulence and antibiotic levels, as the majority of our samples were very purulent because of lung damage. The dependence on purulence of the penetration of antibiotics into sputum has been shown for ampicillin by May and Delves (1965), but we feel in the case of the cystic fibrosis patient with chronic lung infection that this dependence on purulence is not very important, as the purulence in these patients seldom drops.

We conclude that in the treatment of respiratory infections in cystic fibrosis the choice of antibiotic must be influenced not only by the sensitivity of the organism but also by the amount of antibiotic that penetrates into the sputum. Each inflam- 
matory episode should be controlled by detached bacteriological investigations, first isolating the invading organism and then determining its sensitivity to antibiotic discs at $1 \mu \mathrm{g} . / \mathrm{ml}$. and 10 $\mu \mathrm{g} . / \mathrm{ml}$. The best antibiotic in regard to sensitivity and obtainable sputum level can then be chosen, and an accurate minimal inhibitory concentration of the organism against this determined. A careful control of the treatment should then be kept by assays of the sputum antibiotic content and routine sputum culture, for if the sputum level is below that of the minimum inhibitory concentration of the invading organism, even after an increased dosage, a more effective antibiotic must be sought. The possibility of synergistic activity between antibiotics should not be ignored, as in many cases this may be the only means of an effective bacteriological control of the infection.

We are now attempting to put these ideas into practice with cystic fibrosis patients, and so far we have met with some success in controlling staphylococcal infections. In the case of Gram-negative organisms, where the antibiotic concentrations normally required for bacteriological control are greater than those that can be expected in the sputum, the treatment cannot be controlled as above. Antibiotic therapy involving high parenteral dosage, together with aerosolized antibiotics and mucolytic agents, is being used in an attempt to increase the sputum antibiotic levels.

\section{Summary}

The antibiotic levels obtainable in cystic fibrosis sputum by parenteral therapy were studied. The sputum antibiotic content was not directly related to antibiotic blood levels. High molecular weight antibiotics were generally found at higher concentrations in the sputum than were those of low molecular weight.

The authors would like to thank Dr. W. F. Young and Dr. A. P. Norman for specimens of sputum and serum from patients in their care, and the Cystic Fibrosis Research Foundation Trust for a grant.

\section{REFERENCES}

Bond, J. M. (1964). Estimation and use of serum levels in the evaluation of the new penicillins. Postgrad. med.F., 40, Suppl., 17.

Bratton, A. C., and Marshall, E. K., Jr. (1939). A new coupling component for sulfanilamide determination. f. biol. Chem., 128, 537.

Lawson, D., and Saggers, B. A. (1965). N.A.C. and antibiotics in cystic fibrosis. Brit. med. F., 1, 317.

May, J. R., and Delves, D. M. (1965). Treatment of chronic bronchitis with ampicillin: some pharmacological observations. Lancet, 1, 929.

Saggers, B. A., and Lawson, D. (1966). Some observations on the penetration of antibiotics through mucus in vitro. $\mathcal{f}$. clin. Path., 19, 313. 